\title{
Yerel Halkın Festivallerin Başarı Faktörlerini Algılamalarına Yönelik Bir Çalışma: Beypazarı Örneği
}

Öğr. Gör. Ayşe Nevin SERT

Selçuk Üniversitesi, Beyşehir Ali Akkanat Meslek Yüksekokulu, e-posta: nevinsert@gmail.com

\section{Öz}

Her geçen gün artan sayısı ve çeşitliliğiyle festivaller dünyada önemli bir turizm çekicilik unsuru olarak kabul görmektedir. En kısa şekliyle "halk kutlaması" olarak tanımlanan ve sayı bakımından gittikçe artan festivallerin bazıları başarılı olurken bazıları da başarısız olmaktadır. Festivallerin başarılarını etkileyen çeşitli etkenler mevcuttur. Bu etkenlerden birisi de yerel halktır. Yerel halkın festivalleri başarılı görmesi festivallerin gelişmesine ve kalıcılığına olumlu etkide bulunmaktadır. Bu çalışmada yerel halkın festivallerin başarı faktörlerini algılamalarının tespit edilmesine çalışılmıştır. Çalışma kapsamında Beypazarı ilçe sakinlerine anket çalışması uygulanmıştır. Çalışma bulgularına göre yerel halk tarafından festivallerin başarısız olarak algılanması festivallerin gelişimini sekteye uğratmaktadır, olumlu algılanması ise gelişmesine destek sağlamaktadır.

Anahtar kelimeler: Festival, Festival başarı faktörleri, Yerel halk.

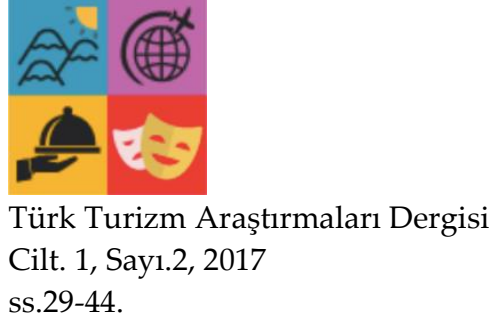

DOI: $10.26677 /$ tutad.2017.7

\section{Önerilen Atıf:}

Sert, A. N., (2017). Yerel Halkın Festivallerin Başarı Faktörlerini Algılamalarına Yönelik Bir Çalışma: Beypazarı Örneği, Türk Turizm Araştırmaları Dergisi, Cilt.1, Sayı.2, ss. 29-44. 


\title{
A Study on Local People Perception of Success Factors of Festivals: Beypazarı Case
}

Lecturer Ayşe Nevin SERT

Selçuk University, Beyşehir Ali Akkanat Vocational School, e-mail: nevinsert@gmail.com

\begin{abstract}
With increasing number and diversity, festivals are accepted as an important tourism attractiveness in the world. Some of the festivals that are defined as "public celebration" are successful, while others fail. There are a variety of factors that affect the success of festivals. One of these factors is the local people. When local people perceive festivals as successful, they positively influence the development and permanence of festivals. In this study, it was tried to determine how the local people perceived the success factors of the festivals. Questionnaires were applied to the residents of Beypazarı district. According to the findings of the study, if local people perceived the festivals positively, they support the development of them. But if the festivals are perceived as unsuccessful by the local people, the development of the festivals is negatively affected.

Keywords: Festival, Festival success factors, Local people.
\end{abstract}

\section{Suggested Citation:}

Sert, A. N., (2017). A Study on Local People Perception of Success Factors of Festivals: Beypazarı, Journal of Turkish Tourism Research, Vol.1, Issue.2, pp. 29-44. 


\section{GİRiş}

Dünyada hızla gelişen endüstrilerin başında yer alan turizm alt yapıyı oluşturucu, iş alanı yaratıcı, gelir büyütücü, döviz sağlayıcı, ödemeler dengesini düzeltici ve değişik sektörlere ait çok sayıda birbirinden farklı ürünleri bir araya getirici özellikleriyle önemli bir gelir kaynağıdır (Pekin, 2011: 32). Dünya Turizm Örgütünün verilerine göre 2016 yılında 1 milyar 235 milyon turist seyahat etmiştir (UNWTO, 2017). Böylesine büyük bir pastadan daha çok pay almak isteyen turizm bölgeleri de çekiciliklerini artırmaya çalışmaktadırlar. Bu noktada festivaller, turizm bölgeleri için önemli bir çekicilik unsuru olarak görülmeye başlanmıştır. Belirli ve gelenekselleşmiş gün ve tarihlerde yapılmak üzere tasarlanmış, toplum yaşamının değerli yönlerini kutlayan temalı halk günleri olarak tanımlanabilecek festivallerin sayıları ve çeşitleri her geçen gün artmaktadır (Small vd., 2005).

Yapılan çalışmalar (Delamere, 1999, 2001; Gürsoy vd., 2002; Felsenstein ve Fleischer, 2003; Small vd., 2005; Ritchie ve Inkari, 2006) festivallerden beklenen faydanın sağlanabilmesi için yerel halkın desteğinin gerekliliğini ortaya koymuştur. Herhangi bir turizm projesi yerel halkın bilgisi haricinde ve desteğinden yoksun olarak planlanmış ve oluşturulmuş ise başarısız olma tehlikesiyle karşı karşıyadır. Festivallerin gelişmesini ve devamlılı̆̆ını sağlamak için yerel halkın tepkisini ve tutumunu belirleyen faktörleri anlamak ve böylece onların desteğini kazanmak gerekmektedir (Gürsoy vd., 2002). Festivallerin başarısıyla olan ilişkisi nedeniyle yerel halkın algılarının ölçülmesi ve hesaba katılmasının gerekliliğinin anlaşılmasından dolayı son yıllarda festivallerin yerel halk tarafından algılanmasına ilişkin yapılan çalışmalar artmaya başlamıştır (Ritchie ve Inkari, 2006). Ray (2000), festivallerin başarısının ve devamlılı̆̆ının yerel halkın desteğine olduğu kadar planlamada ve uygulamada yerel aktörlerin (belediye, kamu kuruluşları, toplumun ileri gelenleri vd.) katılımına da bağlı olduğunu belirtmiştir.

Önemli bir turizm çekicilik unsuru olan festivallere daha önce de belirtildiği gibi her geçen gün bir yenisi eklenmektedir. Buna karşın, bazı festivaller ancak varlığını sürdürebilmekte ve turizm paydaşları için beklenen faydayı sağlamaktadırlar. Festivallerin başarılı olmasında önemli etkenlerden biri yerel halktır. Yerel halk festivalden memnun kalır ve başarılı bulursa festivallere destek vermektedir ve bu destekle festivallerin başarıları artmaktadır. Bu çalışmada Beypazarı festivalinin başarı faktörlerinin yerel halk tarafından nasıl algılandığı ortaya konulmaya çalışılmıştır.

\section{FESTIVALLERINN TANIMI VE KAPSAMI}

Her kültüre mensup insanlar, toplumsal kutlamalar için belirli zaman ayırmış ve bunun gerekliliğini kabul etmişlerdir. Festival olarak adlandırılan bu kutlamalar sadece modern zamanlara ait olmayıp yüzyıllar öncesine dayanmaktadır. Önceleri tarım toplumunun ihtiyaçlarına cevap veren festivaller daha çok hasat kutlamaları şeklindeydi. Ortaçağda dini ritüeller ön plan çıkmıştı. Rönesans döneminde ise dini ritüellerden uzaklaşılıp, günlük aktiviteler festivaller ve karnavallarla birleştirilmişti. 19 . yüzyılın ortalarından itibaren Avrupa'daki toplumsal hayatın ve ortak amaçların bir parçası olan uluslararası festivaller sahneye çıkmıştır (Quinn, 2009). Tarihsel olarak festivaller zor yaşam şartlarıyla akıp giden yeknesak günlük hayata bir değişiklik kattıkları için toplum hayatında daima önemli rol oynamışlardır. Modern dünyada toplumları festival yapmaya iten güçler değişmeye başlamış ve günümüzde artık turist ve turist gelirlerini çekmek için yapılır hale gelmişlerdir (Shone ve Parry, 2004).

Toplumların geçmiş kültür birikimleriyle oluşan ve modern kültürel yaşamın önemli bir özelliğini oluşturan festival, kelime olarak Latince kökenli olup yaygın anlamı da kamu sevinci ve neşesi demektir (Falassi, 1987). Türk Dil Kurumu, festivali, dönemi, yapıldığı çevre, katılanların sayısı veya niteliği programla belirtilen ve özel önemi olan sanat gösterisi olarak tanımlamıştır. Sözlükte yer alan ikinci tanımda ise bir bölgenin en ünlü ürünü için yapılan gösteri, şenlik olarak belirtilmiştir (TDK, 2017). Sözlükteki tanımlar festivali ya sanat gösterisi ya da hasat kutlaması olarak sınırlandırmıştır. Oysa Getz vd., (2010), daha geniş bir perspektiften bakarak festivalleri toplumsal değerlerin, ideolojilerin, 


\section{Ayşe Nevin SERT}

kimliklerin ve sürekliliğin kutlanması, daha modern tanımıla "tema ve/veya halk kutlaması olarak tanımlamışlardır. Bir başka tanıma göre ise festival; dönemi, yapıldı̆̆ı çevre, konusu, katılanların sayısı gibi nitelikleri belli bir programla belirtilen ve özel önemi olan sanat, kültür, bilim, ekonomik faaliyet, ürün, dönem veya belli bir temaya yönelik olarak düzenlenen, tek seferlik veya belli aralıklarla tekrarlanan gösteri ve etkinlikler dizisidir (Atak, 2009). Turizm sınırlı mekân ve zamana bağlı olan süreli bir olgudur (Picard ve Robinson, 2006). Buradan yola çıarak Falassi, (1987), zaman ve mekan kısıtına vurgu yaparak turistlerin, sınırlı bir zaman ve mekân çerçevesinde gelip gittiklerini, festivallerin de zaman ve mekân içinde sınırlı olduğunu belirtmiştir. Janiskee'e (1980) göre festivaller, zevkli aktiviteler, eğlenceler ya da festival karakteri taşıyan etkinliklerdir ya da bazı kavramların, konseptlerin, olayların veya olguların kutlanmasıdır. Başka bir deyişle, festivaller toplumsal refahın ve mutluluğun kutlanmasıdır. Tanımlar ve açıklamalar dikkate alınarak kısaca, festival antik çağlardan günümüze süregelmiş, toplumların kendileri için önemli gördükleri olayların, olguların zaman ve mekanla sınırlı olarak kutlanması olarak tanımlanabilir.

Getz (1989), festivallerin aynı zamanda bir etkinlik olduğunu ve etkinlikler içinde önemli bir yere sahip olduğunu belirtmiştir. Etkinlik toplumsal kimliğin korunmasına ve gelişmesine yardım eden, yapıldığı bölgenin gelişiminde ve çekiciliğinin arttırılmasında önemli rol oynayan organizasyonlar bütünüdür (Karagöz, 2005). Etkinlikler, Olimpiyat ve dünya fuarları gibi mega etkinliklerden festivallere ve açık havada, çeşitli tesislerde yapılan küçük çaplı etkinliklere kadar değişen ölçeklerde yapılan organizasyonların tümü olup, turizmde önemli bir çekicilik unsurudur (Getz, 1991, 1993). Önemli çekicilik unsuru olarak adlandırılan festivaller, özellikle yerel kültüre ilişkin etkinliklerde, otantiklik, özgünlük, misafirperverlik ve erişilebilirliği temsil ederken katılımcılar ve izleyiciler için ise temalandırma ve sembolik unsurların kullanılması gibi özellikleri temsil etmektedir (Derrett, 2004). Bu özelliklerinin yanında ayrıca yerel bilgilerin üretilmesi ve sosyal etkileşim için ortam oluşturur, müşterek kültürel uygulamalar, bir grup veya yerel kolektif aidiyet yaratır; tarihi, sosyal yapıyı ve mirası yeniden oluşturup revize eder (Ekman, 1999).

Felsenstein ve Fleischer (2003)'e göre her geçen gün popülerliği artan festivaller bazı durumlarda gelenekselleşmiş yerel, kültürel ya da dini ritüelleri, turizm etkinliği olarak ya yeniden canlandırılmakta ya da yeniden kurgulanmaktadır. Bazı durumlarda ise yalnızca şehre veya bölgeye turist çekmek için yeni festivaller icat edilmekte ve bunlar desteklenmektedir. Bu ilgilinin nedenlerden birini, ekonomik katkısından dolayı festivallerin yerel halkın harcama gücünü artırmasına ve yaşam standartlarını yükseltmesine bağlayan Felsenstein ve Fleischer, (2003), diğer bir neden olarak da çoğalan boş zamana bağlı olarak kültürel turizm etkinliklerine olan ilginin ve katılımın artmasını göstermişlerdir. Felsenstein ve Fleischer, (2003), arz açısından da konuya yaklaşıp yüksek sabit gideri olan tiyatrolar ve konser organizasyonların yerine düşük maliyetli festivallerin daha cazip gelmesi nedeniyle festivallerin sayısının arttığını ileri sürmüşlerdir. Quinn (2009), festival sayısının hızla artmasını yaratıcılık, boş zaman, sosyalleşme ihtiyacı ve pazar segmentinin "otantik" deneyim yaşamak gibi talep faktörlerine; kenti yeniden konumlandırma, kültürel planlama ve turizmin geliştirilmesi gibi arz faktörlerine bağlayarak özetlemiştir. Festivallerin önem kazanmasını ve popüler olmasını sağlayan başka etkenlerin varlığına da dikkat çeken Quinn, (2009), festivallerin turistlere yerel güzellikler, farklı kültürel ve kolektif deneyimler ile özgün aktivitelere katılma fırsatı sunan neşeli ve şen kutlama özelliği içermeleri bu etkenlerin başında geldiğini vurgulamıştır. Gürsoy vd., (2004) da Felsenstein ve Fleischer, (2003) gibi arz yönüne değinmiş ve festivallerin, pahalı fiziksel yatırımlara dayanmadıkları için eşsiz bir çekicilik unsuru olduklarının altını çizmiştir. Gürsoy vd., (2004) festivallerin büyük oteller, tesisler, doğal güzellikler veya inşa edilmiş çekicilikten çok yerel halkın ve organizatörlerin gayret ve isteğine bağlı olduğunu belirtmiştir. Bununla birlikte küçük finansal yatırımlardan önemli finansal geri dönüşüm kazandırma potansiyeline sahip festivallerin az sermaye istediğini ve var olan altyapıdan yararlandıklarını tespitine yer veren Gürsoy vd., (2004) festivallerin, genellikle gönüllülük esasına ve yerel kontrole dayandığını ifade etmiştir. 
İlkçağlardan bu yana toplumlarda yer bulmuş olan festivallere olan ilgi giderek artmaktadır. Bu ilgilin çeşitli nedenleri bulunmaktadır. Turizm açısından bakıldığında festivallerin önemli bir çekicilik unsuru olması ve tüm paydaşlar için gelir artırıcı özelliği bulunması, büyük yatırımlar gerektirmemesi ve her mevsim düzenlenebilmesi gibi özellikleri başta olmak üzere daha birçok artıları nedeniyle sektörde önemli bir yer tutmaktadır.

\section{FESTIVALLERIN SINIFLANDIRILMASI}

Festivalleri, kriterlerin net bir biçimde tanımlanamamasından dolayı, evrensel bir sınıflandırma içinde değerlendirmenin zor olduğu ileri sürülebilir. Bununla birlikte, Amerika ve Kanada'da hazırlanan festival ve fuar rehberi olan Festival Sourcebook'da, festivaller on sekiz genel kategoriye ayrilmaktadır. Ancak kategoriye ayrılırken uygulanan kriterler açıklanmamıştır

Tablo 1: Festival Kategorileri

\begin{tabular}{|l|l|}
\hline -Yiyecek ve içecek & - Dans \\
- Film & - Etnik etkinlikler \\
- Müzik & - Tarih \\
- Sanat & - Mevsimler \\
- Denizcilik & - Fuarlar \\
- Antika & - Tiyatro ve drama \\
- Sanat ve el sanatları & - Halk \\
- Tarım & - Yaban Hayatı \\
- Toplum & - Kızılderililer \\
& \\
\hline
\end{tabular}

Kaynak: Janiskee, 1991:33.

Tablo 1'de gösterilen festivallerden günümüzde daha yaygın olarak görülen festival türlerine aşağıda yer verilmiştir.

Yiyecek-İ̧ecek Festivali: Farklı temalı birçok festivalde yiyecek-içecek bulunmaktadır. Ancak yiyecekiçecek var olduğu için festivalleri yiyecek-içecek festivali olarak adlandırmak doğru değildir. Yiyecekiçecek festivali, yerel, bölgesel yiyecek-içecekleri öne çıaran ve yiyecek içecekle ilgili programlar ve aktiviteler düzenleyen yiyecek-içecek özellikli festivaldir. Yiyecek-içecek festivali, yerel yiyecekiçeceklerin kutlandığı festivaldir. Yapıldığı bölgelerin hem ekonomisine katkıda bulunan hem de imajını güçlendiren festivale olan ilgi gün geçtikçe artmaktadır (Reid, 2007). Günümüzde Amerika'da yaklaşık 1.000 adet yiyecek-içecek festivali yapılmaktadır (Miller ve Washington, 2012). Şarap festivali de yiyecek-içecek festivali kategorisinde yer almaktadır. Şarap festivali, rekreasyon amaçlı şarap ve turizm endüstrisine entegre olmuş turizmin yeni formu olarak tarif edilebilir (Rivera vd., 2009). Turistler yiyecek-içecek ya da şarap festivaline yiyeceklerin, şarapların tadına bakmak ve özel tatları denemek için gelmektedirler (Park vd., 2008). Bununla birlikte şarap festivalinde, festivalin yapıldığ bölgenin doğal güzelliği de turistler için önemlidir (Rivera vd., 2009).

Film Festivali: Film festivalleri, 1920'lerde film seyredenlerin çoğalıp sinema kulüplerinin ortaya çıkmasıyla yapılmaya başlandığı düşünülmektedir (Batık, 2008). Film festivalleri yapıldıkları bölgeye olumlu ekonomik etkileri olmaktadır. Uluslararası ve ulusal film festivalleri, filmle ilgilenen profesyonelleri, yapımcıları, oyuncuları, yönetmenleri vb. bir araya getirmektedir (Park vd., 2011). Film festivalleri, farklı ulusal sinemalar arasında kültür alışverişini kolaylaştırmak ve alternatif küresel dağıtım ağı sağlamak gibi dünya sinemasında önemli bir görevi de yerine getirmeye çalışmaktadır (Batık, 2008). Ayrıca kültürel etkinliklerle ilgilenen turistler için önemli bir çekicilik unsurudur. Bununla birlikte oluşturduğu ekonomik katkı da göz ardı edilmez. Festival nedeniyle turistlerin ve 


\section{Ayşe Nevin SERT}

profesyonellerin gelmesiyle bölgede ekonomik canlanma olmaktadır. Örneğin her yıl yapılan ve 10 gün süren Santa Barbara festivali yaklaşık 7,3 milyon dolar ek gelir oluşturmaktadır. Ekonomik katkıları yanında yapıldığı bölgenin imajını güçlendirmektedir. Aynı zamanda yerel halkın kültürel etkinliklere katılmasını sağlamaktadır (Park vd., 2011). Ayrıca, film festivalleri Hollwood filmlerinden farklı filmlerin de keşfedilmesine olanak sağlamaktadır (Batık, 2008).

Müzik Festivali: Müzik festivalleri kısa süreli olmaktadır. Buna karşın birçok insanı bir araya getirebilmektedir. Müzik festivali nedeniyle bir araya gelen topluluk arasında "birlik" hissi doğar ve katılanlar uzun süre hafızalarında kalacak deneyimler yaşayabilir. Müzik festivalleri yapıldığı bölgeye hem ekonomik hem de kültürel katkı sağladığından dolayı yaygınlaşmaktadır. Dünyada yaklaşık 70 müzik festivali yapılmaktadır (O'Rourke vd., 2011).

Sanat Festivali: Sanat festivalleri yapıldığı şehrin, bölgenin sanat yaşamına katkıda bulunmakta, sanatın çeşitlin dallarının gelişmesine yardım etmektedir. Sanat festivalleri yalnız sanat yaşamına katkıda bulunmaz aynı zamanda ekonomik ve sosyo-kültürel katkısı da olur (Quinn, 2006). Sanat festivallerinde çeşitli sanat dallarıyla ilgili etkinlikler, sergiler vb. yapılmaktadır. Bu etkinliklerde sanatçılar eserlerini sergilemektedir.

Denizcilik Festivali: Denizle kıyısı olan, halkı denizden faydalanan bölgelerde düzenlenirler. Denizcilik festivalleri, insanlara denizi ve denizciliği tanıtmayı, denizden faydalanmanın önemini, ulaşım yolu olarak kullanmanın yanında denizlerin sunduğu zenginliklerden yararlanmayı, aynı zamanda spor ve hobi olarak da denizciliği sevdirmeyi amaçlamıştır. Denizcilik festivalleri ilk olarak Fransa'da kutlanmıştır. Festivallere ülkelerin Deniz Kuvvetleri de katkı sağlamaktadır. Denizi ve denizciliği topluma sevdirmek amacıyla yapılan festivallere ilgi giderek artmaktadır (Özalp, 2006).

\section{TÜRKIYYE'DE VE DÜNYA’DA FESTIVALLERIN GENEL DURUMU}

Dünyanın her yerinde festivallere ilgi gösterilmektedir. Avrupa ve Amerika'da festivallerin sayı ve çeşitliliği 1960'larda artmaya başlamış, 1980'lerde ivme kazanmış, günümüzde de artmaya devam etmektedir. Aşağıda, ABD ve Kanada' daki festivallerin son 30 yıldaki durumu Tablo 2' de gösterilmiştir.

Tablo 2: ABD ve Kanada'da Festivaller

\begin{tabular}{|l|l|l|l|}
\hline Yıl & Yer & Festival Sayısı (yaklaşık) & Yapıldı̆̆ı Mevsim \\
\hline 1989 & Kanada ve ABD & 4.000 & Nisan -Ekim arası \\
\hline 2012 & Kanada ve ABD & 8.500 & Nisan -Ekim arası \\
\hline
\end{tabular}

Kaynak: Janiskee, 1991; Miller ve Washington, 2012.

Tablo 2'de görüldüğü gibi 1989'un sonunda Kanada ve Amerika'da yapılan festival sayısı 4,000'i aşmıştır (Janiskee, 1991). 2000'li yıllarda bu rakam daha da artmıştır. 2012'de sadece Amerika Birleşik Devletlerinde yapılan film festivali 150'ye ulaşmıştır (Miller ve Washington, 2012). Festival sayısı toplamda \%100'den daha fazla oranda artmıştır. Amerika'da ve Avrupa'da yapılan festivallerin yaklaşık \%87'si Nisan ve Ekim ayları arasında gerçekleştirilmektedir (Janiskee, 1991).

Avrupa'da da, önemli bir çekicilik unsuru kabul edilen festivaller ilgi görmektedir. Örneğin, Almanya'da her yıl "Volkfest" olarak adlandırılan 14.000 festival düzenlenmektedir (Festival Worlds, 2006). Ayrıca, Berlin film festivali, Cannes Film festivali yapıldıkları şehre ve ülkeye önemli katkılarda bulunmaktadır. Ayrıca Avrupa festival düzenlemeyi kurumsal bir yapı haline de getirmiştir. 1952 yılında Cenova'da kurulan Avrupa Festivaller Birliği (Europen Festivals Association-EFA) bugün, 40 ülkedeki ulusal festival dernekleri ve kültürel ağlarıyla işbirliği içinde çalışmalarını sürdürmektedir. 
Türkiye'de festivallerin sayısı son 20-30 yılda artmış olup 2015 yllı itibariyle toplam 1254 festival düzenlenmiştir (Giritlioğlu vd., 2015).

Tablo 3: Türkiye' de Düzenlenen Festivallerin Aylara, Temalara ve Bölgelere Göre Dağılımı

\begin{tabular}{|c|c|c|c|c|c|}
\hline Aylar & Say1 & Temalar & Say1 & Bölgeler & Say1 \\
\hline Ocak & 14 & Kültür & 508 & Marmara & 463 \\
\hline Şubat & 19 & Sanat & 284 & Karadeniz & 268 \\
\hline Mart & 25 & Yiyecek İçecek & 205 & Ege & 173 \\
\hline Nisan & 32 & Spor & 127 & İç Anadolu & 148 \\
\hline Mayıs & 110 & İş & 62 & Akdeniz & 111 \\
\hline Haziran & 224 & Diğer & 68 & Doğu Anadolu & 60 \\
\hline Temmuz & 362 & & & Güney Doğu Anadolu & 31 \\
\hline Ağustos & 225 & & & & \\
\hline Eylül & 144 & & & & \\
\hline Ekim & 40 & & & & \\
\hline Kasım & 15 & & & & \\
\hline Aralık & 14 & & & & \\
\hline \multicolumn{6}{|c|}{ Toplam 1254} \\
\hline
\end{tabular}

Kaynak: Giritlioğlu vd., 2015.

Tablo 3`de görüldüğü gibi ülkemizde festivaller daha çok bahar ve yaz aylarında düzenlenmektedir. Bölge olarak da Marmara ve Karadeniz bölgelerinde yoğunlaşmaktadır. Kültür ve sanat festivallerinin sayı diğer festivallerden daha fazla olduğu görülmektedir.

Şehir bazında bakıldığında ise İzmir 53 etkinlikle ilk sırada yer alırken, bunu 38 etkinlikle Antalya, 32 etkinlikle Ankara ve 29 etkinlikle İstanbul izlemektedir. En az etkinlik düzenlenen iller arasında, Diyarbakır, Ağrı, Bitlis, Bayburt, Elazı̆̆, Kilis, Siirt, Yalova, Şanlıurfa ve Kırşehir dikkati çekmektedir. İstanbul, Ankara, İzmir ve Antalya gibi büyük kentlerde gerçekleştirilen uluslararası kültür-sanat festivalleri de yaygındır. İstanbul, uluslararası kültür-sanat festivalleri ve sponsorlu festival etkinlikleri bakımından her yıl bahar ve yaz aylarında diğer kentlere oranla büyük bir yoğunluk yaşamaktadır. Ülkemizde düzenlenmekte olan, aynı zamanda uluslararası değer taşıyan kültür ve sanat festivallerinin uluslararası platformda her geçen yıl önemini arttırmaktadır (Bilgili vd., 2012).

\section{FESTIVALLERDE BAŞARIYI ETKILEYEN FAKTÖRLER}

Festivaller, özellikle de bölgesel festivaller, istihdam artışı gerçekleştirerek ve bölgesel ürünlerin satışını artırarak önemli bir gelir kaynağı olarak yerel halkın ekonomik durumunu canlandırmak amacıyla düzenlenmektedir (Kim vd., 2008). Ancak düzenlenen festivallerin hepsi belirlenen hedeflere ulaşamamaktadır. Festivallerin istenilen başarıya ulaşmasında bazı faktörler önemli rol oynamaktadır. Festivallerin canlılığı, etkinliği ve uzun vadeli sürdürülebilirliği konuşulurken neden bazı festivallerin başarısız olduğu, bazılarının ise başarılı olup, yapıldıkları yerlerde önemli bir turistik çekicilik haline geldiği tartışılmakta, araştırmalara konu olmaktadır. Dolayısıyla araştırmacılar tarafından festivallerin başarılı veya başarısız olmalarını belirleyen faktörler ortaya konulmaya çalışılmaktadır. Lade ve Jackson (2004) bu faktörleri üç başlık altında toplarken Kim vd., (2008), yöre halkının desteği konusuna dikkat çekerken Getz (1997), ise organizasyonun önemine değinmiştir. Bazı araştırmacılar ise festivalin soysal etkilerine vurgu yaparak yerel halkın festivalin sosyal etkilerini algılama biçimlerinin bu algıların 


\section{Ayşe Nevin SERT}

olumlu ya da olumsuz olmasının önemli bir başarı faktörü olarak değerlendirmişlerdir (Hinch ve Delamere, 1993; Delamere, 1997, 2001; Small vd., 2005; Sharpley ve Stone, 2011).

Lade ve Jackson, (2004) festivallerin temel başarı faktörlerini üç kategoriye ayırmıştır, ancak her ne kadar kategorilere ayrılmışsa da aralarında bir etkileşim olduğu görülmektedir. Söz konusu faktörler; (1) toplumun katılımı ve desteği, (2) yönetim ve planlama fonksiyonu ve (3) pazarlama stratejileridir (Lade ve Jackson, 2004). Kim vd., (2008) festivallerin başarılı olmasında önemli faktörlerden birinin de toplumda festivali destekleyenlerin bulunması olduğunu ileri sürmüşlerdir. Bunlar yöre halkı, belediye ve kaymakamlıktır. Yöre halkı, belediye ve kaymakamlığın koordinasyon halinde çalışmasıyla festivalin başarıya ulaşması mümkün olmaktadır. Bu durumda festival organize edilirken destek sağlayacak bu kaynakların iyi organize edilmesi gerekliliği önemli bir nokta olup festivali organize edenlerin destek ve kaynak sağlayacak kurum ve kişileri bir araya getirebilecek ve organize edebilecek ilişkiler kurabilmeleri gerekmektedir (Andersson ve Getz, 2008). Görüldüğü gibi yerel halk başarı faktörlerinde temel faktör olarak rol oynamaktadır.

Lade ve Jakson'a (2004) göre yerel halkın festivali başarı bulmasında yerel yönetimlerle işbirliği içinde olmalarının etkisinin büyük olduğunu belirtmiştir. Yerel yönetim (kaymakamlık ve belediye) yerel halkla birlikte koordinasyon içinde hareket ettiğini düşünmesi halinde yerel halkın festivale olan ilgisi ve desteği artmaktadır. Bachleitner ve Zins'e (1999) göre de yerel halk karar verme sürecine dahil edildiğine inanması festivallere karşı tutumlarını olumlu yönde etkiler. Herhangi bir oluşumun başarısı ve sürdürülebilirliği yerel halkın aktif desteği olmadan mümkün değildir. Aktif desteğin verilmediği durumda aktif muhalefet, oluşumu ya engeller ya da bu oluşumun tamamen durmasına neden olabilir. Bundan dolayı yerel toplum desteğinin önemi geniş kabul görmüş ve gittikçe gelişen bir araştırma alanı haline gelmiştir (Delamere, 1999, 2001; Wilosn vd., 2002; Gürsoy ve Rutherford, 2004).

\section{YÖNTEM}

\section{Araştırmanın Evren ve Örneklemi}

Bilimsel araştırmalar geneli temsil ettiğine inanılan küçük bir kütlenin özelliklerinin tekrar genele atfedilmesi mantı̆̆ı etrafında yapılmaktadır. Buradan yola çıkarak; evren araştırmacının çalışma alanını oluşturan, örneğini seçtiği ve edindiği sonuçları genelleştireceği bir grup olarak tanımlanabilir (Altunışık vd., 2002). İki tür evren vardır, bunlardan birincisi, genel evren ve öteki ise erişilebilir araştırma (çalışma) evrenidir. Genel evren soyut bir kavram olup, tanımlanması kolay ancak ulaşılması zordur. Araştırma evreni ise ulaşılması mümkün olan evrendir ve bu açıdan somuttur (Karasar 2011: 110). Yapılan tanım çerçevesinde, araştırmanın evrenini Türkiye'de festival düzenleyen kırsal turizm bölgelerinde yaşayan yerel halk oluşturmaktadır. Erişilebilir araştırma evreni ise Beypazarı'nda yaşayan yerel halk olarak tanımlanmıştır. Örneklem belli bir evrenden, belli kurallara göre seçilmiş ve seçildiği evreni temsil yeterliliği kabul edilmiş olan küçük küme olarak tanımlanmaktadır. Buna göre, araştırmalar örneklem üzerinde yapılır ve elde edilen sonuçlar ilgili evrene genellenir (Karasar, 1995: 110). Örnekleme ise bir süreç olup bir çalışmada evreni temsil edecek bireylerin belirlenmesidir.

Bilimsel araştırmalarda araştırma evreninin tamamına ulaşılabileceği gibi erişilebilir araştırma evreni içerisinden belirli bir yöntem ile seçilebilecek örneklem aracılığı ile de temsil edilebilir (Altunışık vd., 2002). Buna göre, bu araştırmada zaman, maliyet ve ulaşılabilirlik sebeplerinden dolayı evrenin tamamına ulaşmak yerine örneklem alınma yoluna gidilmiştir. Araştırmanın erişilebilir araştırma evreni olarak Beypazarı sakinleri seçilmiştir. Beypazarı'nın erişilebilir araştırma evreni olarak seçilmesinin nedenlerinden biri ilçenin tarihi, kültürel ve doğal turistik çekiciliklere sahip olması ve özellikleriyle Türkiye'nin önemli bir iç turizm yöresi olduğu varsayılmasıdır. Kırsal turizm bölgesi olan ilçede, turizm önemli bir geçim kaynağıdır. Ayrıca ilçenin çalışma alanı olarak seçilmesinin bir diğer önemli nedeni ise, ilçede önemli turistik çekicilik unsuru olan "Uluslararası Beypazarı ve Yöresi Festivalinin her yıl yapılmakta olmasıdır. Söz konusu festivalin yöre halkı üzerinde sosyal, kültürel, ekonomik ve çevresel etkileri olabileceğinden yola çıkılarak araştırma alanı olarak Beypazarı ilçesinin 
yerinde bir tercih olduğu düşünülmektedir. Araştırma kapsamında kolayda örnekleme yöntemi kullanılmıştır. Kolayda örnekleme, ankete cevap veren herkesin örneğe dahil edildiği bir örnekleme yöntemidir. Anket işlemi arzu edilen örnek büyüklüğüne ulaşıncaya kadar devam eder (Gegez, 2007).

14-15.05.2012 tarihlerinde Beypazarı ilçesinde yaşayan yöre halkına 320 adet anket uygulanmıştır. Anket uygulaması bizzat Beypazarı'na gidilerek yapılmıştır. Anketler yüz yüze yapılmış olup, anketör kullanılmamıştır. Anketler festivalin yapıldığı ilçenin merkezinde uygulanmıştır. Eksik ve hatalı olması nedeniyle 24 adet anket elenmiş ve değerlendirmeler 296 anket üzerinden yapılmıştır.

\section{Araştırma Verilerinin Toplanması}

Kırsal turizm bölgelerinde yerel halkın festivallerin başarı faktörleriyle ilgili algılarını ölçmek amacıyla örneklemden elde edilecek verilerin toplanmasında anket tekniğinden yararlanılmıştır. Veri toplamada sık başvurulan tekniklerden biri olan anket, cevaplandırıcının daha önce belirlenmiş bir sıralamada ve yapıda oluşturulan sorulara karşılık vermesiyle veri elde etme yöntemidir (Altunışık, 2002, 71). Veri toplama aracı olan anketin geliştirilmesinde Lade ve Jacson (2004)'ın makalelerinde yer alan ölçekten yararlanılmıştır. Veriler üzerinde gerekli çözümlemeleri yapabilmek amacıyla örneklem büyüklüğü 296 birim yeterli kabul edilmiştir. İfadeler 5'li Likert ölçeğindeki "1=Kesinlikle Katıllyorum", "2=Katıllyorum", " $3=\mathrm{Ne}$ Katıliyorum $\mathrm{Ne}$ Katılmiyorum", " $4=$ Katılmıyorum", " $5=$ Kesinlikle Katılmıyorum" seçenekleriyle derecelendirilmiştir. Katılımcılardan bu dereceden durumuna uygun herhangi birisini işaretlemesi istenmiştir. Ankette yer alan boyutlar itibariyle belirlenen ölçek maddeleri akademisyenlerin değerlendirmesine sunulmuş, akademisyenlerden ölçek maddelerinin çalışmanın amacına uygunluğunu ve anlaşılırlığını değerlendirmeleri istenmiştir. Bu değerlendirmelere ilişkin görüşlere göre ifadeler düzeltilmiş ve ankete son hali verilmiştir.

\section{Araştırma Verilerinin Analizi}

Beypazarı ilçesinde yaşayan yöre halkını kapsayan ve 296 katılımcıdan anket aracıllı̆ı̆yla elde edilen veriler, sosyal bilimlerde veri analizi için kullanılan SPSS 15.0 programına girilmiştir. Veri girişinin ardından veriler değerlendirilerek araştırmanın problem, amaç ve konusuna uygun olarak analiz edilmiştir. Araştırmadan elde edilen verilerin öncelikle frekans dağılımları çıkarılmış, faktör analizi ve kümeleme analizleri yapılmıştır.

\section{Araştırma Yapılan Beypazarı İlçesine Yönelik Tanımlayıcı Bilgiler}

Araştırma alanı olan Beypazarı, İç Anadolu Bölgesi'nin Yukarı Sakarya Bölümü'nde Ankara ili sınırları içinde yer almaktadır. Ankara'ya 99 km uzaklıkta olan ilçe, merkezde iki ve üç katlı evlerden oluşan sıkışık bir yerleşim şekline sahiptir. Konumu ve geleneksel mimarinin korunma altında olması nedeniyle yeni yerleşimler eski kentin çevresinde ve özellikle ilçeyi başkente bağlayan ana yolun kıyısında kuruludur. İlçenin nüfusu, 2008 yılı sayım sonuçlarına göre, 46,768 olup \%70'i tarım alanında çalışmaktadır (Kara, 2011). İlçenin yüzölçümü 1.868 km. ve rakımı 675 m’dir.

\section{BULGULAR}

Bu kısımda araştırmaya ait verilerin analiz sonuçlarına yer verilmektedir. Tablo 4 'de katılımcıların demografik değişkenlerine ilişkin frekans bilgileri bulunmaktadır.

Ankete katılan Beypazarı sakinlerinin demografik özellikleri ile ilgili verilerin analizinde yüzde ve frekans dağılımından yararlanılmıştır. Buna göre katılımcıların \%31,4'ü kadın ve \%68,6'sı erkektir. Anketi cevaplayanların yaş dağılımları genelde $\% 29,7^{\prime}$ si 21-30, \%27,7'si 31-40, \%20,6'sı 41-50, \%13,2'si 51-60, 5.1'i 20 yaş ve altı ve son olarak \%3,7'si 61 ve üzeri yaş grubunda yoğunlaşmaktadır. Eğitim durumu incelendiğinde, \%41,2 ile lise mezunu olan katılımcıların en yüksek orana sahip olduğu görülmektedir. Söz konusu katılımcıların haneye giren aylık gelir miktarı değerlendirildiğinde, büyük çoğunluğunun gelirinin 801-1500 TL arası olduğu (\%33,1) gözlenmektedir. Çalışmada erkek oranının yüksek çıkması anketin uygulandığı çarşı esnafı ve çalışanların çoğunluğunun erkek olması ve dışarıda 


\section{Ayşe Nevin SERT}

daha fazla erkeğin bulunması olduğu düşünülmektedir. Lise mezunu oranının yüksek çıkması ilçenin konumu, sosyo-ekonomik yapısı, eğitim imkanları ve diğer özellikleriyle ilişkilendirilebilir.

Tablo 4: Araştırmaya Katılan Beypazarı Sakinlerinin Demografik Özellikleri

\begin{tabular}{|l|c|c|l|c|c|}
\hline & $\mathbf{n}$ & $\mathbf{\%}$ & & $\mathbf{n}$ & $\mathbf{\%}$ \\
\hline Cinsiyet & & & Çalışma Durumu & & \\
\hline Kadın & 93 & 31,4 & Memur & 20 & 6,8 \\
\hline Erkek & 203 & 68,6 & Özel Sektör Çalışanı & 95 & 32,1 \\
\hline Toplam & 296 & 100 & Serbest Meslek & 81 & 27,4 \\
\hline Yaş & & & Çiftçi & 10 & 3,4 \\
\hline$<=20$ & 15 & 5,1 & İşçi & 63 & 21,3 \\
\hline $21-30$ & 88 & 29,7 & Ö̆ğrenci & 10 & 3,4 \\
\hline $31-40$ & 82 & 27,7 & Ev Hanımı & 8 & 2,7 \\
\hline $41-50$ & 61 & 20,6 & Çalışmıor & 9 & 3,0 \\
\hline $51-60$ & 39 & 13,2 & Memur & 20 & 6,8 \\
\hline 61 ve üzeri & 11 & 3,7 & Gelir & & \\
\hline Toplam & 296 & 100 & 800 TL'den az & 65 & 22,0 \\
\hline Eğitim Durumu & & & $801-1500$ TL arası & 98 & 33,1 \\
\hline İlkokul & 60 & 20,3 & $1501-2000$ TL arası & 72 & 24,3 \\
\hline İlköğretim & 49 & 16,6 & $2001-2500$ TL arası & 35 & 11,8 \\
\hline Lise & 122 & 41,2 & $2501-3000$ TL arası & 13 & 4,4 \\
\hline Üniversite ve üstü & 65 & 22,0 & 3000 TL ve üzeri & 13 & 4,4 \\
\hline Toplam & 296 & 100 & Toplam & 296 & 100 \\
\hline
\end{tabular}

Tablo 5: Beypazarı Sakinlerinin Festivalle İlgili Memnuniyetlerine ilişkin Frekans ve Yüzde Dağılımı

\begin{tabular}{|l|c|c|}
\hline Memnuniyet durumu & $\mathbf{n}$ & $\mathbf{\%}$ \\
\hline Hiç memnun olmayanlar & 3 & 1,0 \\
\hline Memnun olmayanlar & 5 & 1,7 \\
\hline Kararsılar & 16 & 5,4 \\
\hline Memnun olanlar & 137 & 46,3 \\
\hline Oldukça memnun olanlar & 135 & 45,6 \\
\hline Toplam & 296 & 100 \\
\hline
\end{tabular}

Tablo 5'e bakıldığında, anketi cevaplayan 296 kişiden, 3'ünün $(\% 1,0)$ festivalden hiç memnun olmadığı, 5 'nin $(\% 1,7)$ memnun olmadığı, 16'sının $(\% 5,4)$ karasız olduğu, 137 kişinin $(\% 46,3)$ memnun olduğu, 135 kişinin ise $(\% 45,6)$ oldukça memnun olduğu tespit edilmiştir. Festivalden memnuniyet oranı yüksektir. İlçe halkı festivalin katkılarını, faydasını yüksek bulduğu için memnuniyet oranı yüksek çıkmıştır.

Tablo 6'da araştırmaya katılanların değerlendirmelerine yönelik her bir ifadeye verdikleri cevaplara ilişkin frekans ve yüzde dağılımları ile aritmetik ortalama ve standart sapmalar yer almaktadır. Söz konusu tabloya göre katılımcıların festivalin başarı faktörleriyle ilgili değerlendirmesine yönelik olarak verilen ifadelere gösterdikleri katılım oranları verilmiştir. 
Tablo 6: Araştırmaya Katılanların Festivalin Başarı Faktörleriyle İlgili Düşüncelerine İlişkin Bulgular

\begin{tabular}{|c|c|c|c|c|c|c|c|c|}
\hline \multicolumn{2}{|l|}{$\begin{array}{l}\text { Katılımcıların Festivalin Başarı Faktörleriyle İlgili } \\
\text { Düşüncelerine İlişkin İfadeler }\end{array}$} & 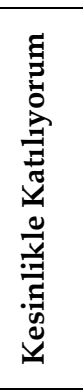 & 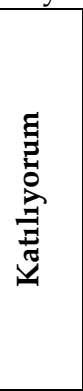 & 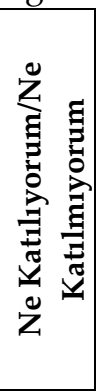 & 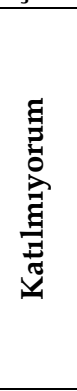 & 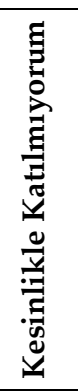 & 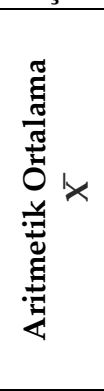 & 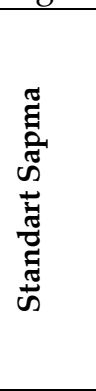 \\
\hline \multirow{2}{*}{ Belediye festivale destek sağlamaktadır. } & $\mathrm{N}$ & 124 & 143 & 23 & 4 & 2 & \multirow[t]{2}{*}{4.29} & \multirow[t]{2}{*}{.726} \\
\hline & $\%$ & 41.9 & 48.3 & 7.8 & 1.4 & 0.7 & & \\
\hline \multirow{2}{*}{ Kaymakamlık festivale destek sağlamaktadır. } & $\mathrm{N}$ & 101 & 132 & 50 & 9 & 4 & \multirow[t]{2}{*}{4.06} & \multirow[t]{2}{*}{.866} \\
\hline & $\%$ & 34.1 & 44.6 & 16.9 & 3.0 & 1.4 & & \\
\hline \multirow{2}{*}{$\begin{array}{l}\text { Belediye, kaymakamlık ve işletmeler eşgüdüm } \\
\text { içinde çalışmaktadır. }\end{array}$} & $\mathrm{N}$ & 92 & 152 & 36 & 11 & 5 & \multirow[t]{2}{*}{4.06} & \multirow[t]{2}{*}{.858} \\
\hline & $\%$ & 31.1 & 51.4 & 12.2 & 3.7 & 1.7 & & \\
\hline \multirow{2}{*}{$\begin{array}{l}\text { İlçemiz halkı festivale manevi destek } \\
\text { sağlamaktadır. }\end{array}$} & $\mathrm{N}$ & 77 & 162 & 34 & 13 & 10 & \multirow[t]{2}{*}{3.96} & \multirow[t]{2}{*}{.909} \\
\hline & $\%$ & 26.0 & 54.7 & 11.5 & 4.4 & 3.4 & & \\
\hline \multirow{2}{*}{$\begin{array}{l}\text { Festivale ilçemizdeki küçük turizm işletmeleri } \\
\text { maddi katkı sağlamaktadır. }\end{array}$} & $\mathrm{N}$ & 63 & 149 & 46 & 22 & 16 & \multirow[t]{2}{*}{3.74} & \multirow[t]{2}{*}{1.044} \\
\hline & $\%$ & 21.3 & 50.3 & 15.5 & 7.4 & 5.4 & & \\
\hline \multirow{2}{*}{$\begin{array}{l}\text { Festivale ilçemizdeki zengin işadamları maddi } \\
\text { katkıda bulunmaktadır. }\end{array}$} & $\mathrm{N}$ & 61 & 126 & 59 & 34 & 16 & \multirow[t]{2}{*}{3.61} & \multirow[t]{2}{*}{1.101} \\
\hline & $\%$ & 20.6 & 42.6 & 19.9 & 11.5 & 5.4 & & \\
\hline \multirow{2}{*}{$\begin{array}{l}\text { İlçe halkı festival için gönüllü olarak } \\
\text { çalışmaktadır. }\end{array}$} & $\mathrm{N}$ & 65 & 126 & 41 & 45 & 19 & \multirow[t]{2}{*}{3.58} & \multirow[t]{2}{*}{1.175} \\
\hline & $\%$ & 22.0 & 42.6 & 13.9 & 15.2 & 6.4 & & \\
\hline \multirow{2}{*}{$\begin{array}{l}\text { İlçemiz halkı festivale maddi destek } \\
\text { sağlamaktadır. }\end{array}$} & $\mathrm{N}$ & 46 & 95 & 55 & 52 & 48 & \multirow[t]{2}{*}{3.12} & \multirow[t]{2}{*}{1.322} \\
\hline & $\%$ & 15.5 & 32.1 & 18.6 & 17.6 & 16.2 & & \\
\hline
\end{tabular}

Not: 1: Kesinlikle Katılmıyorum, 5: Kesinlikle Katılıyorum.

"Belediye festivale destek sağlamaktadır." İfadesi için ortaya çıkan ortalama ( $X=4.29)$, olarak gerçekleşmiştir. Bu ifadeye "Kesinlikle katılıyorum" ve "Katıllyorum" diyenler toplam olarak \% 90.2 'lık bir dilimi oluşturmaktadır. Katılımcıların oransal çoğunluğu olumlu yönde görüş bildirmiştir. "Kaymakamlık festivale destek sağlamaktadır." İfadesi için alınan görüşlerin ortalaması ( $X=4.06)$, dır. Ankete katılanların toplamda \% 78,7'si "Kesinlikle katılıyorum" ve "Katılıyorum" şeklinde görüş bildirmiştir. "Belediye, kaymakamlık ve işletmeler eşgüdüm içinde çalışmaktadır." ( $X=4.06)$, olarak gerçekleşmiştir. Ankete katılanların toplamda \% 82,5'i "Kesinlikle katılıyorum" ve "Katılıyorum" demiştir. "İlçemiz halkı festivale manevi destek sağlamaktadır". ( $X=3.96)$, ifadesine katılımcıların \% 80,7' si "Kesinlikle katıliyorum" ve "Katılıyorum" demiş ancak "İlçemiz halkı festivale maddi destek sağlamaktadır." ( $X=3,12)$,ifadesine cevapları \% 47,6's1 "Kesinlikle katılıyorum" ve "Katılıyorum", \% 33,8 ise " Kesinlikle katılmıyorum" ve "Katılmıyorum" olmuştur. "Festivale ilçemizdeki küçük turizm işletmeleri maddi katkı sağlamaktadır." ( $X=3.74)$, Katılımcıları \% 71,6'sı "Kesinlikle katılıyorum" ve "Katılıyorum" olarak görüşlerini ortaya koymuşlardır. "Festivale ilçemizdeki zengin işadamları maddi katkıda bulunmaktadır. "( $X=3,61)$, ifadesine katılımclların \% 63,2'si "Kesinlikle katıliyorum" ve "Katılıyorum" demiştir. "İlçe halkı festival için gönüllü olarak çalışmaktadır." (X=3.58), ifadesi için katılımcıların \% \%64,6 "Kesinlikle katılıyorum" ve "Katılıyorum" şeklinde görüş bildirmiştir.

Festivalin başarı faktörlerine ilişkin değerlendirmelerini ölçmek için hazırlanmış olan Likert türü soruda, katılımcıların vermiş oldukları cevapları gruplandırılması amacıyla faktör analizi uygulanmıştır. 
Tablo 7: Festivalin Başarı Faktörlerine İlişkin KMO ve Bartlett’s Testi sonuçları

\begin{tabular}{|l|l|c|}
\hline \multicolumn{2}{|c|}{ KMO ve Bartlett's Test } \\
\hline Kaiser-Meyer-Olkin Measure of Sampling Adequacy. & 0,792 \\
\hline Bartlett's Test of Sphericity & Approx. Chi-Square & 857.186 \\
\cline { 2 - 3 } & Df & 28 \\
\cline { 2 - 3 } & Sig. &, 000 \\
\hline
\end{tabular}

Tablo 7'de KMO ve Bartlett küresellik testinin sonuçları yer almaktadır. Buna göre festivalin başarı faktörlerine ilişkin maddelerin KMO oranının $(0,792)$ ve Bartlett küresellik testi sonucunun faktör analizi uygulamak için yeterli olduğu görülmektedir.

Tablo 8: Festivalin Başarı Faktörlerine İlişkin Maddelerin Faktör Analizi sonuçları

\begin{tabular}{|c|c|c|c|c|}
\hline Maddeler & \multicolumn{2}{|c|}{$\begin{array}{l}\text { Faktör } \\
\text { Yüküu }\end{array}$} & \multirow[t]{2}{*}{$\begin{array}{c}\text { Açıklanan } \\
\text { Ortak } \\
\text { Varyans } \\
\% \\
\end{array}$} & \multirow[t]{2}{*}{$\begin{array}{l}\text { Cronbach's } \\
\text { Alpha }\end{array}$} \\
\hline Faktör 1: Yerel Yönetim Başarı Faktörleri & 1 & 2 & & \\
\hline Kaymakamlık festivale destek sağlamaktadır. & 0.895 & & 45.985 & \multirow{9}{*}{0.791} \\
\hline $\begin{array}{l}\text { Belediye, kaymakamlık ve işletmeler eşgüdüm içinde } \\
\text { çalışmaktadır. }\end{array}$ & 0.857 & & & \\
\hline Belediye festivale destek sağlamaktadır. & 0.821 & & & \\
\hline \multicolumn{4}{|l|}{ Faktör 2: Yerel Halk Başarı Faktörleri } & \\
\hline $\begin{array}{l}\text { Festivale ilçemizdeki küçük turizm işletmeleri maddi } \\
\text { katkı sağlamaktadır. }\end{array}$ & & 0.804 & \multirow{5}{*}{23.218} & \\
\hline İlçemiz halkı festivale maddi destek sağlamaktadır. & & 0.786 & & \\
\hline $\begin{array}{l}\text { Festivale ilçemizdeki zengin işadamları maddi katkıda } \\
\text { bulunmaktadır. }\end{array}$ & & 0.652 & & \\
\hline İlçe halkı festival için gönüllü olarak çalışmaktadır. & & 0.650 & & \\
\hline İlçemiz halkı festivale manevi destek sağlamaktadır & & 0.574 & & \\
\hline \multicolumn{3}{|c|}{ Toplam Açıklanan Varyans } & 69,203 & \\
\hline
\end{tabular}

Not: 1: Kesinlikle Katılmıyorum, 5 Kesinlikle Katılıyorum.

Tablo 8 incelendiğinde, faktör analizi sonucunda toplam açıllanan ortak varyans değeri (\%69.203) ve Cronbach Alfa değeri $(0,791)$ olarak hesaplanmıştır. Bu değerlere göre ölçeğin yapı geçerliliğinin istenen düzeyde olduğu görülmektedir. Veri setine faktör analizi uygulandığında, festivalin başarı faktörlerine ilişkin sekiz maddenin iki faktörde toplandığı tespit edilmiştir. Buna göre, "Faktör 1: Yerel yönetim başarı faktörleri" (Kaymakamlık ve belediyenin festivale desteği ve işbirliği) ve "Faktör 2: Yerel halk başarı faktörleri" (Yerel halkın, işletmelerin maddi - manevi desteği) olarak sınıflandırılmıştır.

Başarı faktörüne ilişkin kümeleme analizi sonuçları Tablo'9 da yer almaktadır. 
Tablo 9: Genel Başarı Faktörüne İlişkin Maddelerin Küme Sayıları

\begin{tabular}{|l|l|c|}
\hline \multicolumn{3}{|c|}{ Her Kümeye İsabet Eden Gözlem Sayısı } \\
\hline \multirow{2}{*}{ Genel Başarı Faktörü } & 1 Yüksek & 279 \\
\cline { 2 - 3 } & 2 Düşük & 17 \\
\hline Geçerli veri & 296 \\
\hline Kayıp veri & 0 \\
\hline
\end{tabular}

Genel başarı faktörünün 8 değişkenine ilişkin 296 katılımcının vermiş olduğu cevaplarla "yüksek ve düşük" olarak 2 küme elde edilmiştir. Buna göre 279 (\%94.3) katılımcı yüksek nitelendirilen kümede, 17( \%5.7) katılımcı düşük nitelendirilen kümede yer almaktadır (Tablo 9). İki grup arasındaki farklılıkların incelenmesi için t-testi kullanılmıştır. Verilen cevaplara t-testi uygulanması sonucunda küme ortalamaları birbirinden farklı iki küme oluştuğu gözlenmiştir $(p=0,0001<0,05)$. Elde edilen kümeler "yüksek" ve "düşük" şeklinde sınıflandırılmıştır.

Tablo 10: Yerel Halk Başarı Faktörüne İlişkin Maddelerin Küme Sayıları

\begin{tabular}{|l|l|c|}
\hline \multicolumn{2}{|c|}{ Her Kümeye İsabet Eden Gözlem Sayısı } \\
\hline \multirow{2}{*}{ Yerel Halk Başarı Faktörü } & 1 Yüksek & 258 \\
\cline { 2 - 3 } & 2 Düşük & 38 \\
\hline Geçerli veri & 296 \\
\hline Kayıp veri & 0 \\
\hline
\end{tabular}

Tablo 10'da görüldüğü gibi yerel halk başarı faktörünün 5 değişkenine ilişkin 296 katılımcının vermiş olduğu cevaplarla "yüksek ve düşük" olarak 2 küme elde edilmiştir. Buna göre 258 (\%87.2) katılımc1 festivalin başarısında yerel halkın katılımını yüksek nitelendirilen kümede, 38 (\%12.8) katılımcı düşük nitelendirilen kümede yer almaktadır. İki grup arasındaki farklılıkların incelenmesi için t-testi kullanılmıştır. Verilen cevaplara t-testi uygulanması sonucunda küme ortalamaları birbirinden farklı iki küme oluştuğu gözlenmiştir $(\mathrm{p}=0,0001<0,05)$. Elde edilen kümeler "yüksek" ve "düşük" şeklinde sınıflandırılmıştır. Buna göre festivalin başarısında yerel halkın payını yüksek olduğu görülmektedir.

Tablo 11: Yerel Yönetim Başarı Faktörüne İlişkin Maddelerin Küme Sayıları

\begin{tabular}{|l|l|c|}
\hline \multicolumn{2}{|c|}{ Her Kümeye İsabet Eden Gözlem Sayısı } \\
\hline \multirow{2}{*}{ Yerel Yönetim Başarı Faktörü } & 1 Yüksek & 286 \\
\cline { 2 - 3 } & 2 Düşük & 10 \\
\hline Geçerli veri & 296 \\
\hline Kayıp veri & 0 \\
\hline
\end{tabular}

Tablo 11'de yerel yönetim başarı faktörünün 3 değişkenine ilişkin 296 katılımcının vermiş olduğu cevaplarla "yüksek ve düşük" olarak 2 küme elde edilmiştir. Buna göre 286 (\%96.6) katılımcı festivalin başarısında yerel yönetimin payını yüksek nitelendirilen kümede, 10(\%3.4) katılımcı düşük nitelendirilen kümede yer almaktadır.

\section{TARTIŞMA VE SONUÇ}

Festivalden memnun olma oranı oldukça yüksek çıkmıştır. 137 kişinin $(\% 46,3)$ memnun olduğu, 135 kişinin ise $(\% 45,6)$ oldukça memnun olduğu tespit edilmiştir. Beypazarı sakinlerinin festivalden memnun oldukları görülmektedir.

Festival başarı faktörleri ise "Yerel Yönetim Başarı Faktörleri” ve "Yerel Halk Başarı Faktörleri” olmak üzere iki başlık altında toplanmıştır. Faktör analizinde "Yerel yönetim başarı faktörü" olarak çıkan 


\section{Ayşe Nevin SERT}

ifadelere katılım oranı yüksektir. Belediye ve kaymakamlığın festivale destek verdiğine dair ifadelere katılım dikkat çekicidir. Belediyenin festivale destek vermesiyle ilgili ifadeye $\% 90$ oranında katılım elde edilmiştir. Kaymakamlığın destek vermesiyle ilgili ifade ise \%78 oranında kabul görmüştür. Kaymakamlığın, belediyenin ve işletmelerin eş güdüm içinde çalıştığını düşünen katılımcının oranı ise \%82'dir. İfadelere katılım oranlarının yüksek olması, yöre halkının "Beypazarı ve Yöresi Festivalini" başarılı bulduğunu göstermektedir. Bu başarıda Belediyenin ve Kaymakamlığın rolünün büyük olduğu görüşünün hakim olduğu ortaya çıkmaktadır. Belediye ve kaymakamlık arasındaki koordinasyonun da iyi olduğu görülmektedir. Bu sonuçlar literatürle paralellik göstermektedir. Festivallerin başarılı olabilmesi için yerel yönetimler tarafından desteklenmeli ve yöre halkı, belediye, kaymakamlık koordinasyon halinde çalışmalıdır (Lade ve Jackson, 2004; Andersson ve Getz, 2008; Kim vd., 2008). Yerel Halk Başarı Faktörü altında yöre halkının festivale manevi destek verdiği (\%80,7), maddi destek verdiği $(\% 47,6)$, küçük turizm işletmelerinin $(\% 71,6)$ ve zengin işadamlarının $(\% 63,2)$ maddi destek sağladığı ifadeleriyle yerel halkın festival için gönüllü çalıştıkları $(\% 64,6)$ ifadeleri toplanmıştır. Küçük turizm işletmeleriyle, zengin işadamlarının desteği yüksek çıkmıştır. Yerel halkın festivale maddi destekten çok manevi destek verdiği sonucu çıkmıştır. Yerel Halk Başarı Faktörü altında toplanan ifadelere katılım yüzdelerine bakıldığında yöre halkının festivale desteğinin fazla olduğu görülmektedir. İlçe halkı, festivalin başarılı olduğu kanısındadır. Zengin işadamları, esnaf ve yöre halkı da festivale destek vermekte, gönüllü çalışmalara katılmaktadırlar. Aynı zamanda, belediyenin ve kaymakamlığın desteği oldukça yüksektir. Araştırma paydaşlar arasında oldukça iyi bir eşgüdüm olduğunu da göstermiştir.

Yapılan araştırma sonuçları yöre halkının Beypazarı'nda yapılan Beypazarı ve Yöresi Festivalinden memnun olduklarını, festivali olumlu algıladıklarını ortaya koymaktadır. Bu festivalin ilçelerine ve kendilerine katkı sağladığını düşünmektedir. Buna bağlı olarak ilçe halkı, festivalin başarılı olduğu kanısındadır. Zengin işadamları, esnaf ve yöre halkı da festivale destek vermekte, gönüllü çalışmalara katılmaktadırlar. Aynı zamanda, belediyenin ve kaymakamlığın desteği oldukça yüksektir. Araştırma paydaşlar arasında oldukça iyi bir eşgüdüm olduğunu da göstermiştir. Yerel toplumun festivalin başarısı açısından önemi literatürde geniş kabul görmüş ve desteklenmiştir. Yöre halkı tarafında festivallerin başarısız olarak algılanması festivallerin gelişimini sekteye uğratmaktadır, olumlu algılaması ise gelişmesini sağlamaktadır. Festivallerin başarısı ve sürdürülebilirliği, organizasyonu yapanların tüm paydaşlar için zenginlik, değer ve memnuniyet yaratabilmesiyle yakından ilgilidir (Lade ve Jackson, 2004; Gürsoy ve Rutherford, 2004: Arcodia ve Whitford, 2006; Akova, 2006; Andersson ve Getz, 2008; Kim vd., 2008; Karlsen ve Nordstrom, 2009).

Festivallerin başarılı olmasında yerel halkın etkin bir rol oynadığı görülmektedir. Yerel halkın festivalin başarı faktörlerini algılama şekli festivale destek verip vermemelerinde önemlidir. Dolayısıyla yerel halk festivalin önemli bir paydaşı olarak görülmeli ve karar alma mekanizmasına dâhil edilmelidir. Böylece yöre halkı da yapılan organizasyonun bir parçası haline gelir ve sahiplenme hissi kuvvetlenebilir.

\section{KAYNAKÇA}

Altunışık, R., Çoşkun, R. ve Bayraktaroğlu, S. (2002). Sosyal Bilimlerde Araştırma Yöntemleri. Sakarya: Sakarya Kitapevi.

Andersson,T. and Getz, D. (2008). Stakeholder Management Strategies of Festivals, Journal of Convention E Event Tourism, 9(3):199-220.

Arcodia, C. and Whitford, M. (2007). Festival Attendance and The Development of Social Capital. Journal of Convention \& Event Tourism, 8(2):1-18.

Bachleitner, R. and Zins, AH. (1999). Cultural Tourism in Rural Communities, The Residents' Perspective. Journal of Business Research, 44 (3):199-209. 
Batık, E. (2008). International Film Festivals and Local Forms of Colonialism (Doctoral Dissertation, Middle East Technical University).

Delamere, T. A. (1999). Development of A Scale to Measure Local Resident Perceptions of the Social Impacts of Community Festivals. Ninth Canadian Congress on Leisure Research, Wolfville.

Delamere, T.A. (2001). Development of A Scale to Measure Residents Attitudes Toward the Social Impacts of Community Festivals, Part II: Verification of The Scale. Event Management, 7:25-38.

Derrett, R. (2004). Festivals, Events and The Destination. Festival and Event Management: An International Arts and Culture Perspective, Oxford: Butterworth-Heinemann.

Ekman, A. K. (1999). The Revival of Cultural Celebrations in Regional Sweden: Aspects of Tradition and Transition. Sociologia Ruralis, 39(3):280-293.

Falassi, A. (1987). Festival: Definition and Morphology. In A. Falassi (Ed.), Time Out of Time. Essays on the Festival (1-10) (Albuquerque, NM: University of New Mexico Press).

Felsenstein, D. and Fleischer, A. (2003). Local Festivals and Tourism Promotion: The Role of Public Asistance and Vsitor Ependiture. Journal of Travel Research, 41(4):385-392.

Gegez, E. (2007). Pazarlama Araştırmaları. İstanbul: Beta Basım Yayım.

Getz, D. (1989). Special Events. Defining The Product. Tourism Management, 10(2):135-137.

Getz, D. and Frisby, W. (1990). "A Study of the Role of Municipalities in Developing Festivals and Special Events in Ontario," Occasional Paper No. 16. Waterloo: University of Waterloo, Department of Recreation and Leisure Studies, 38-44

Getz, D. (1991). Festivals, Special Events, And Tourism. New York: VanNostrand Reinhold.

Getz, D. (1993). Festivals and Special Events. In M. A. Khan, M. D. Olsen, and T. Var (Eds.), Encyclopedia of Hospitality and Tourism (789-810). New York:NY: Van Nostrand Reinhold.

Getz, D. (1997). Event Management \& Event Tourism. New York: Cognizant Communication Corporation.

Getz, D., Andersson, T. and Carlsen, J. (2010). “Festival Management Studies Developing a Framework and Priorities for Comparative and Cross-Cultural Research. International Journal of Event and Festival Management, 1(1):29-59.

Giritlioğlu, İ., Olcay, A., ve Özekici, Y. K. (2015). Bir Turizm Çeşitliliği Olarak Festival Etkinliklerinin Sınıflandırılması: Türkiye Üzerine Bir Değerlendirme. Sosyal Bilimler Araştırmaları Dergisi, (13):306-323.

Gürsoy, D., Jurowski, C. and Uysal, M. (2002). Resident Attitudes: A Structural Modeling Approach. Annals of Tourism Research, 29 (1):79-105.

Gürsoy, D. and Rutherford, D. G. (2004). Host Attitudes Toward Tourism: An Improved Structural Model. Annals of Tourism Research, 31(3):495-516

Gürsoy, D., Kim, K. and Uysal, M. (2004). Perceived Impacts of Festivals and Special Events by Organizers: An Extension and Validation, Tourism Management, 25:171-181.

Hinch, T. and Delamere, T.A (1993). Native Festivals as Tourism Attractions. A Community Challenge. Journal of Applied Recreation Research, 18 (2):131-142.

Janiskee, R. (1980). South Carolina's Harvest Festivals: Rural Delights for Day Tripping Urbanites. Journal of Cultural Geography, 1(1):96-104.

Janiskee, R. (1991). Rural Festivals in South Carolina. Journal of Cultural Geography, 11(2):31-43. 


\section{Ayşe Nevin SERT}

Karagöz, D. (2006). Etkinlik turizmi ve etkinlik turizmi bağlamında yabancı ziyaretçi harcamalarının ekonomiye etkisi: Formula 12005 Türkiye Grand Prix Örneği. Basılmamış Yüksek Lisans Tezi. Eskişehir: Anadolu Üniversitesi Turizm İşletmeciliği Anabilim Dalı.

Karasar, N. (1995). Bilimsel araştırma yöntemi (7. Basım). Ankara: Nobel Yayınevi.

Karlsen,S. and Nordstrom, C.S. (2009). Festivals in The Barents Region: Exploring Festival-Stakeholder Cooperation, Scandinavian Journal of Hospitality and Tourism, 9(2-3):130-145.

Kim, Y., Kim, S. and Agrusa, J. (2008). An Investigation into The Procedures Involved in Creating the Hampyeong Butterfly Festival as an Ecotourism Resource, Successful Factors, And Evaluation. Asia Pacific Journal of Tourism Research, 13(4):357-377.

Lade, C. and Jackson, J. (2004). Key Success Factors in Regional Festıvals: Some Australian Experiences. Event Management, 9:1-11.

Miller, R. and Washington, K. (2012). Leisure Business Market Research Handbook. Atlanta: Richard K. Miller \& Associates.

O'Rourke, S., Irwin, D. and Straker, J. (2011). Dancing to Sustainable Tunes: An Exploration of Music Festivals and Sustainable Practices in Aotearoa. Annals of Leisure Research, 14 (4):341-354.

Özalp, E. İ.(2006). Marmaris Uluslar Arası Denizcilik Festivalinin Denizciliğin ve Deniz Kuvvetlerinin Tanıtımına Katkısı. Marmara Üniversitesi, Sosyal Bilimler Enstitüsü, İletişim Bilimleri Anabilim Dalı, Halkla İlişkiler Bilim Dalı. İstanbul.

Picard, D. and Robinson, M. (2006). Festivals, Tourism and Social Change: Remaking Worlds, Channel View Publications, Clevedon: England.

Ray, C. (2000). Endogenous Socio-Economic Development in The European Union Issues of Evaluation. Journal of Rural Studies, 16(4):447-458.

Reid, S. (2007). Identifying Social Consequences of Rural Events. Event Management, 11(1-2):89-98.

Ritchie, B. and Inkari, M. (2006). Host Community Attitudes Toward Tourism and Cultural Tourism Development: The Case of the Lewes District, Southern England. International Journal of Tourism Research. 8(1):27-44.

Sharpley, R and R. Stone, P. (2011). Socio-Cultural Impacts of Events: Meanings, Authorized Transgression, And Social Capital. In S. Page and J. Connell (Eds) The Routledge Handbook of Events. London: Routledge.

Shone, A. and Parry, B. (2004). Successful Event Management: A Practical Handbook. Thomson Learning.

Small, K., Edwards, D. and Sheridan, L. (2005). A Flexible Framework for Evaluating the Socio-Cultural Impacts of A (Small) Festival. International Journal of Event Management Research, 1(1):66-76.

Rivera, D., J, Chandler and Winslow, H. (2009). Developing A Profile of Visitors at A North Carolina Wine Festival: Pilot Test. The Consortium Journal, 14(2):5-20.

Türk Dil Kurumu (TDK). (2017). Festival. Güncel Türkçe Sözlük. http://www.tdk.gov.tr/index.php?option=com_gts\&arama=gts\&guid=TDK.GTS.5524cca29b4de4.25064 107 adresinden, 20 Mayıs 2017 tarihinde alınmıştır.

Quinn, B. (2009). Festivals, Events and Tourism. School of Hospitality Management and Tourism. Dublin Institute of Technology, The SAGE Handbook of Tourism Studies, London, Sage, 483-503.

Wilson, S., Fesenmaier, D., Fesenmaier, J. and Van ES, J. (2002). Factors for Success in Rural Tourism Development, Journal of Travel Research, 40(2):132-138. 